\title{
CLARIS-La Plata Basin: regional hydroclimate variability, uncertainties and climate change scenarios
}

\author{
Jean-Philippe Boulanger ${ }^{1,4}$, Andrea F. Carril ${ }^{2}$, Enrique Sanchez ${ }^{3, *}$ \\ ${ }^{1}$ LOCEAN, UMR CNRS/IRD/UPMC, Tour 45-55/Etage 4/Case 100, UPMC, 4 Place Jussieu, \\ 75252 Paris Cedex 05, France \\ ${ }^{2}$ Centro de Investigaciones del Mar y la Atmósfera (CIMA/CONICET-UBA), C1428GA Buenos Aires, Argentina \\ ${ }^{3}$ Universidad de Castilla-La Mancha (UCLM), 45071 Toledo, Spain \\ ${ }^{4}$ Present address: 672 Rue du Mas de Verchant, Immeuble MIBI, 34000 Montpellier, France
}

\begin{abstract}
The CLARIS-LPB project, funded from 2008 to 2012 by the $7^{\text {th }}$ Framework Programme of the European Commission, aimed at projecting regional climate change impacts in the La Plata Basin (LPB) in southeastern South America focusing on the periods 2010-2040 and 2070-2100. Such a coordinated projection of regional climate change scenarios was key in successfully designing adaptation strategies for land-use, agriculture, rural development, hydropower production, river transportation, water resources and wetland ecosystems. Topics covered in this special include characteristics of climate variability over the region, together with trends, extreme events and uncertainties for modelled regional climate projections.
\end{abstract}

KEY WORDS: Modelling $\cdot$ Regional climate change $\cdot$ South America $\cdot$ Extremes

The CLARIS-LPB project brought together around 200 scientists from various disciplines, whose research objectives included: (1) to improve the description and understanding of decadal climate variability for short-term regional climate change projections (2010-2040); (2) to improve the capacity to predict climate change and its impacts in the region, through an ensemble of coordinated regional climate scenarios. This ensemble would allow quantification of the amplitude and sources of uncertainties in the La Plata Basin (LPB) future climate for 2 time periods: 20102040 (near future) and 2070-2100 (far future). The near-future period would be key for adaptation strategies, and the far future for assessment of long-term impacts; (3) to design adaptation strategies for regional scenarios of climate change impacts through multi-disciplinary research; (4) to involve stakeholders in the design of adaptation strategies through an inter-

*Corresponding author: e.sanchez@uclm.es active and communicative process, ensuring dissemination of information to public, private and governmental policy-makers; (5) to foster long-term collaborations between European and South American partners; and (6) to train young scientists in relevant disciplines at South American and European institutes.

The research groups involved in CLARIS-LPB and more specifically in this Special - collaborated to estimate the robustness of the ensemble of regional climate change projections, with special focus on the most important scientific issues over the region, that is: decadal and interdecadal variability, the effects of such variability on climatic extremes over the LPB, and trends and uncertainties in global climate model (GCM) projections, in particular from the CLARIS-LPB regional model ensemble, since it is the first coordinated regional ensemble of climate change projections over South America.

() The authors 2016. Open Access under Creative Commons by Attribution Licence. Use, distribution and reproduction are unrestricted. Authors and original publication must be credited. 
An overview of the main features, uncertainties and trends obtained from the ensemble of regional climate models (RCMs) and their projections can be seen in Carril et al. (2016) and Solman (2016). Carril et al. (2016) relate the RCM data to several indices of extremes, while Solman (2016) analyzes systematic biases that were obtained from both ERA-Interimand GCM-forced RCM ensembles by comparing both against the Climate Research Unit observational database. Gallardo et al. (2016) describe an overall picture of the main climatic characteristics of the South American continent using the ERA-Interimforced RCM ensemble, showing how these are projected (using the GCM-forced RCM ensemble) to change during the $21^{\text {st }}$ century. López-Franca et al. (2016) inspect changes in temperature extremes, while Cavalcanti \& Silveira (2016) study changes in mean and extreme precipitation. A combination of extreme temperature and precipitation events and the associated atmospheric circulation as predicted by the ensemble of RCMs is studied by Tencer et al. (2016). Marengo et al. (2016) use the Eta regional climate model to study the change in hydrometeorological conditions for the end of the $21^{\text {st }}$ century over the Brazilian Pantanal area.

A better understanding of the main physical atmospheric processes at regional scales relevant to the LPB region is also a crucial issue. One of the more important processes is related to the land surface and atmospheric feedbacks. These mechanisms are studied using observations (Penalba et al. 2016) and an ensemble of RCMs (Menéndez et al. 2016). Cold front structures, analyzed from the RCM simulations, are studied by de Jesus et al. (2016).

Climate variability over the region is another very important topic included in this Special, which is covered in 3 contributions: Cazes-Boezio \& Talento (2016) analyze the impact of La Niña events over the southeastern region of South America during the austral summer; Grimm et al. (2016) study the interdecadal variability related to extreme precipitation events in the monsoon season; and the ENSO influence simulated by a GCM is described in Tedeschi et al. (2016).

This Special shows the potential of the first coordinated RCM ensemble for South America to be used to better understand the climate of the region. It also offers opportunities for further studies (e.g. pure cli- mate studies) and provides a foundation for impact and adaptation strategies in the La Plata Basin region for the $21^{\text {st }}$ century.

\section{LITERATURE CITED}

Carril AF, Cavalcanti IFA, Menéndez CG, Sörensson A and others (2016) Extreme events in the La Plata Basin: a retrospective analysis of what we have learned during CLARIS-LPB project. Clim Res 68:95-116

Cavalcanti IFA, Silveira VP (2016) Precipitation and extreme changes over the La Plata Basin from CLARIS-LPB regional models. Clim Res 68:169-182

Cazes-Boezio G, Talento S (2016) La Niña events before and after 1979 and their impact in southeastern South America during austral summer: role of the Indian Ocean. Clim Res 68:257-276

de Jesus EM, da Rocha RP, Reboita MS, Llopart M, Mosso Dutra LM, Remedio ARC (2016) Contribution of cold fronts to seasonal rainfall in simulations over the southern La Plata Basin. Clim Res 68:243-255

> Gallardo C, Gil V, Tejeda C, Sánchez E, Gaertner MA (2016) Köppen-Trewartha classification used to assess climate changes simulated by a regional climate model ensemble over South America. Clim Res 68:137-149

Grimm AM, Laureanti NC, Rodakoviski RB, Gama CB (2016) Interdecadal variability and extreme precipitation events in South America during the monsoon season. Clim Res 68:277-294

> López-Franca N, Zaninelli PG, Carril AF, Menéndez CG, Sánchez E (2016) Changes in temperature extremes for 21st century scenarios over South America derived from a multi-model ensemble of regional climate models. Clim Res 68:151-167

> Marengo JA, Alves LM, Torres RR (2016) Regional climate change scenarios in the Brazilian Pantanal watershed. Clim Res 68:201-213

> Menéndez CG, Zaninelli PG, Carril AF, Sánchez E (2016) Hydrological cycle, temperature, and land surfaceatmosphere interaction in the La Plata Basin during summer: response to climate change. Clim Res 68:231-241

Penalba OC, Rivera JA, Pántano VC, Bettolli ML (2016) Extreme rainfall, hydric conditions and associated atmospheric circulation in the southern La Plata Basin. Clim Res 68:215-229

> Solman SA (2016) Systematic temperature and precipitation biases in CLARIS-LPB ensemble simulations over South America and possible implications for climate projections. Clim Res 68:117-136

- Tedeschi RG, Cavalcanti IFA, Grimm AM (2016) ENSO influence on La Plata Basin precipitation in the HadGEM2-ES model. Clim Res 68:295-307

> Tencer B, Bettolli ML, Rusticucci M (2016) Compound temperature and precipitation extreme events in southern South America: associated atmospheric circulation, and simulations by a multi-RCM ensemble. Clim Res 68: 183-199 